\title{
Valuation of a Residential Building using Land and Building, Rental Income and Composite Rate Method
}

\author{
B. Prakash Rao
}

\begin{abstract}
The art of estimating the meaningful present worth of the commodity or property based on experience, logical approach, relevant statistical data etc. is termed as Valuation of properties such as buildings, factories, other engineering structures of various types, land etc. It determines the present value of properties. This study is focused on the valuation of a residential house of Ground plus one upper floor. The objective of this study is to compare the values obtained by three different methods of valuation and identifying the most appropriate one for the property under consideration. The methods of valuation that are used in the process are: Land and Building method, Rental method and Composite rate method. Depreciation is also given due importance in all the methods. In land and building method, the value of land and the value of the building are estimated independently to obtain the present value of the property. Rental method involved capitalizing the net annual rental income using a suitable rate of interest. Composite rate method is also employed to determine the present value based on the prevailing market rates. Breakup of composite rate for the building under valuation is calculated based on the breakup of composite rate of the building under comparison For the independent residential house, it is observed that Land and Building method showed the least variation from the Fair Market value (INR 7500000 approximately). The value obtained by Land and Building method is INR 7700000.The value obtained through composite rate method is INR 8300000, whereas the value obtained using rental method of valuation is INR5500000.
\end{abstract}

Keywords: Valuation, Land and Building method; Rental method; Composite rate method; depreciation, Fair market value

\section{INTRODUCTION}

$\mathrm{V}$ aluation is the process of estimating the fair price, based on the particular case and purpose for which valuation is needed. This depends on the material date of valuation, place and market condition.

The following are few of the purposes of valuation:

- Purchase for investment or for occupancy

- Tax fixation

- Sale of property

- Rent fixation

- Determine Insurance Premium

- Mortgage value or Security of loans

- Compulsory Acquisition

- Fixing Betterment charges

Revised Manuscript Received on October 31, 2019.

* Correspondence Author

Prof. B.Prakash Rao*,Associate Professor ( Senior Scale), Department of Civil EngineeringManipal Institute of Technology,Manipal Academy of Higher Education,Manipal,India. Email:bp.rao@manipal.edu
- Gift tax

\section{A. Process of valuation}

In the valuation of buildings, the usual method employed is to ascertain the prime cost of a building and to account for depreciation to give the present day market value. The prime cost is the value a similar structure will cost to erect taking into account all the ornamental features which have a market value.

\section{B. Depreciation}

Depreciation is the decrease in value of the property due to wear, tear, decay and obsolescence

\section{Approach}

For valuation of buildings, generally, the cost approach is adopted. In cost approach, several engineering methods have been employed. in estimating the building cost such as unit in place methods or inventory of the quantities of material and labor, plinth area and cubical content methods, Land and building method, Rental income method and Composite rate method etc.

The value depend on original cost of construction of building, cost of major capital repairs carried out, the maintenance of the building, present condition of the building, general wear and tear of the building, cost of major immediate capital repairs required if any, efficiency of carpet area, parking facilities, general light and ventilation conditions of the building, the orientation with respect to windward direction, flow of natural air, quality of materials and workmanship and so on. It also depends on services available like water supply, drainage, electricity, underground water tank, overhead water tank, pumps, provision of bore well, type of electrification, compound wall and gate, approach road, provision of lift, capacity to raise further floors over the existing buildings etc.

Factors on which value of Building depends are:

- The present depreciated value of the building, its age, and useful economic future life.

- The prevailing value of the land similarly situated round about this area.

- The situation, shape, size, topography, elevation and frontage of the plot of land.

- The extent of end use and utility. Services available such as schools, market, hospitals, recreation centres, parks etc.

\author{
Published By: \\ Blue Eyes Intelligence Engineering
}


- Communication and transportation facilities such as posts, telegraphs, telephone, electricity, roads, railways, buses etc. and their locations in the vicinity.

- Type of locality i.e. industrial, residential or commercial and also the status of locality,i.e. poor class, middle class or upper class.

- Predominant character of the neighborhood area.

The objective of this study is to determine the value of an Independent residential building using three different approaches and to compare the same with the Fair Market value prevailing in that locality

\section{LITERAURE REVIEW}

Vinaly Kaul et.al (2005) [10] highlighted the points to be looked into for valuing the property of commercial type in the international market. N.Ravindran ( 2006) [9] made use of Land and building method, Rental Income method and Composite rate method to determine the value of a building. Michael C. Dalbor et al. (2006) [3] detailed the derivation of restaurant demand and it is based on common knowledge rather than the commonly used methods. The various methods include capitalization rate, buyer and seller determination according to tangible and intangible assets and according to annual revenue and good-will. D.Krishnaraj(2013) [7] wrote about the calculations of deprecation based on the age of the building. He further suggests not to consider the enhanced value of salvages of the upper floors as they are either newer or less than the age of the ground floor. Abhishek Golchha and S.S Pimplikar, (2016) [1] wrote about valuing triple storied residential complex. The valuation of building is determined by plinth area method. Byrne, P; (1995) [4] carried out a comparison of fuzzy procedures with those used in conventional risk analysis approaches. Differencing data series enables the class of models to extend to non-stationary series called Autoregressive Moving Average (ARIMA) models popularized by Box and Jenkins (1970) [6]. Tse (1997) [5] applied the Box-Jenkins method for the study of Hong Kong's real estate prices. David and Wayne, (1979) [8]; Granger and Newbold, (1974) [2] independently established ARIMA as a time-series based approach to economic forecasting.

\section{METHODOLOGY}

The following methodology is adopted

$>$ Collection of all the required plans and drawings

$>$ Visit to the property under valuation and the property under comparison

Application of Land and Building method

Application of Rental Income method

> Application of Composite Rate method

\section{A. Land and Building method}

By this method, the value of the land and the value of Building are assessed separately and added to get the present value of the property. Later suitable depreciation is accounted.

\section{B. Rental Income Method}

Rental method of valuation consists in capitalizing the Net Annual Rental Income (NARI) at an appropriate rate of interest or rate of capitalization. Net annual rent income equals to Gross Annual Rental Income (GARI) minus outgoings like Property Tax, repairs, maintenance, Service Charges, Insurance.

\section{Composite rate method}

In this method, breakup of composite rate for the building under valuation is calculated based on the breakup of composite rate of the building under comparison. Using this composite rate, the value of the building is found

\section{VALUTION USING DIFFERENT METHODS AND RESULTS}

\section{A. General Details of the Building under valuation}

Land extent: 72.6 feet $x 60$ feet $=4356 \mathrm{sft}(10$ cents)

Plinth area constructed $=2521.23 \mathrm{sft}$

Ground Floor- 1629.55 sft; First Floor- $891.68 \mathrm{Sft}$

Construction year-2013, Monthly rent for a similar

building in that locality $=20000 /$ month

Location: Kundapura, Udupi District, Karnataka, India

Composite rate for a similar new property adjacent to this building $=$ INR 2500 (700 for land +1800 for construction)

FSI allowed for the building to be valued is 1.50

FSI achieved by the similar property under comparison $=1.50$

Date of valuation: June 2019

Note: 1 Acre of land $=100$ cents; 1 cent of land $=435.6$ square feet (sft), $1 \mathrm{~m}=3.28$ feet $1 \mathrm{sqm}=10.76 \mathrm{sft}$

1 United States Dollar (USD) is nearly $=70$ Indian Rupees (INR) as of June 2019

The figures are shown in Appendix

Figure 1.shows the Ground Floor plan of the Residential building under valuation

Figure 2.shows the First Floor plan of the Residential building under valuation

Figure 3.shows the Sectional Elevation of the Residential building under valuation

\section{B. Land and Building Method}

Value of Land:

Land extent $\mathrm{x}$ Land rate $=4356 \times 700=3049200$

Value of Building:

Total Plinth area $\times$ Rate of construction=2521.23 x 1800

$=4538214$

\section{Depreciation:}

Age of the building $=2019-2013=6$ Years

Considering a salvage value of $10 \%$ and assuming the building life of 60 years,

Depreciation $=(6 / 60) \times(100-10)=9 \%$

i.e. $9 \%$ of $4538214=408439.26$

Depreciated value of the building $=4129774.74$

Total Value $=$ Land value + Depreciated value of the building+ value of compound wall $3049200+4129774.74+500000=7678974.74$

say INR 7700000 


\section{Rental Income Method}

Monthly rent=INR 20000

Gross rent $=12 \times 20000=240000$

Allowing a nominal $15 \%$ deduction for annual

repairs, maintenance etc. $=36000$

Net rent $=204000$

Rate of return is around 5\% in that locality

Capitalizing @ $5 \%$ in perpetuity, Years Purchase

(YP) $=1 / 0.05=20$

Capitalized value $=$ Net rent $\mathrm{X} Y \mathrm{P}$

$=20 \times 204000=4080000$

FSI achieved $=$ Total plinth area constructed/extent of land= 2521.23/4356=0.579

Load appurtenant $=$ FSI allowed $\mathrm{x}$ Built up area in the Ground

floor $=1.50 \times 1629.55=2444.32 \mathrm{sft}$

Excess Land available $=4356-2444.32=1911.68 \mathrm{sft}$

Value of excess land $=$ land rate $\mathrm{x}$ excess land

$=700 \times 1911.68=1338176$

Total Value $=4080000+1338176$

$=5418176$

say INR 5500000

\section{Composite Rate Method}

Total plinth area constructed $=2521.23 \mathrm{sft}$

Land extent $=4356 \mathrm{sft}$

FSI achieved $=2521.23 / 4356=0.579$

FSI achieved by the building under comparison

$=1.50$

Composite rate of the building under comparison

$=2500 / \mathrm{sft}$

Break up of composite rate of the building under comparison with FSI achieved $=1.50$

Value of Land component

$=$ Land Rate $/$ FSI achieved $=700 / 1.50=466.67 / \mathrm{sft}$

Rate of building component $=2500-466.67$

$=2033.33$

Break up of composite rate for the building under valuation

FSI achieved $=2521.23 / 4356=0.579$

Rate of land component $=700 / 0.579=1208.98$

Rate of building component $=2033.33$

Depreciation for 6 years $=(6 / 60) \times(100-10)=9 \%$

Depreciated rate of building component

$=2033.33-9 \%$ of $2033.33=1850.33$

Composite rate $=1850.33+1208.98=3059.31$, say $3060 / \mathrm{sft}$

Value of the property $=3060 \times 2521.23=7714963.80$

Total value $=7714963.80+$ value of compound wall

$(500000)=8214963.80$,

say INR 8300000

\section{RESULT AND DISCUSSION}

The three methods of valuation do not arrive at the same value It can be seen that, the value obtained by Land and Building method (INR 7700000) is nearer to the Fair Market value which is close to INR 7500000. This is due to the factor that the land is valued separately at its present market value and the building is also valued independently based the amenities, size of rooms, quality of construction, quality of materials used and so on. In this study, the value obtained using Composite rate method (INR 8300000) is also fairly close to the fair market value wherein amenities, size of rooms, quality of construction, quality of materials used are taken care off. However the Rental method of valuation arrives at a value much below the fair market value. This method depends on the rent, the building can attract and the various outgoings. This is very obvious that the property under valuation is situated in a small town Kundapura in Udupi District and hence the rents obtainable for buildings will be less in this locality, particularly for residential buildings. The rental method of valuation works out be close to fair market value in localities where there is a huge demand for rental buildings. This happens in big cities, particularly for commercial buildings.

The value of any real property will depend on the purposes of valuation. For the purpose of Tax fixation one has to follow the guidelines set by the local Government authority. Insurance premium calculation will be based on the value for the type of insurance. The seller and the purchaser will have different perspectives in arriving at the value of the property of their interest. However the valuer must use his expertise, knowledge and commonsense to arrive at the most reasonable value which is close to Fair Market Value.

\section{CONCLUSION}

Through a comprehensive study over a period of four months, the following results are obtained:

The value arrived at using three different methods are

Land and Building method-

nearly INR 7700000

Composite Rate Method-

nearly INR 8300000

Rental Income method-

nearly INR 5500000

However the present fair market value of this property is observed to be nearly INR 7500000. The value obtained by Land and Building method is nearer to the Fair Market value for the building under consideration. This may vary depending on the type of property, location etc. It is also seen that the value found out using Rental Income method is far below the Fair Market value. 
APPENDIX

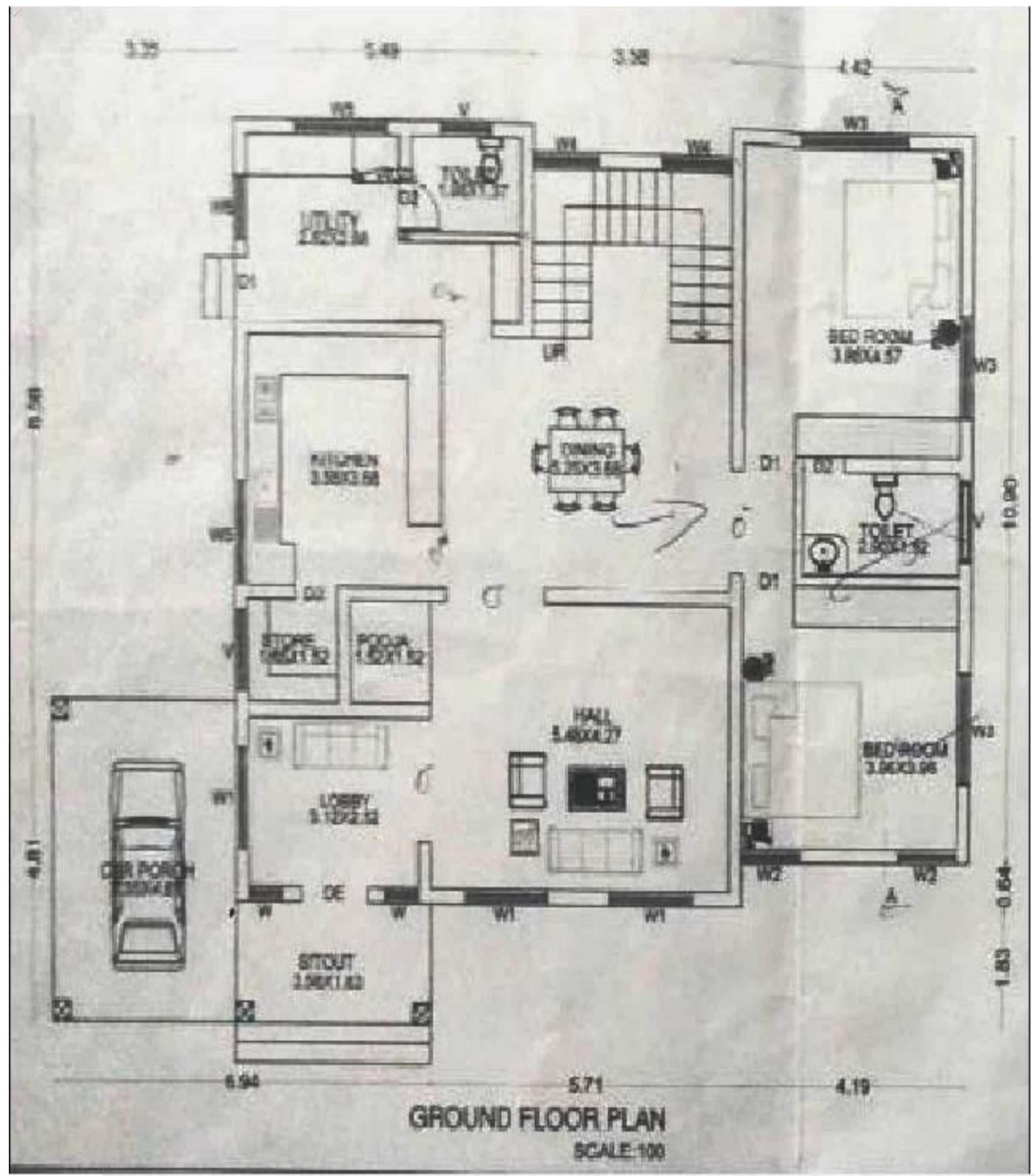

Fig.1. Ground Floor Plan 


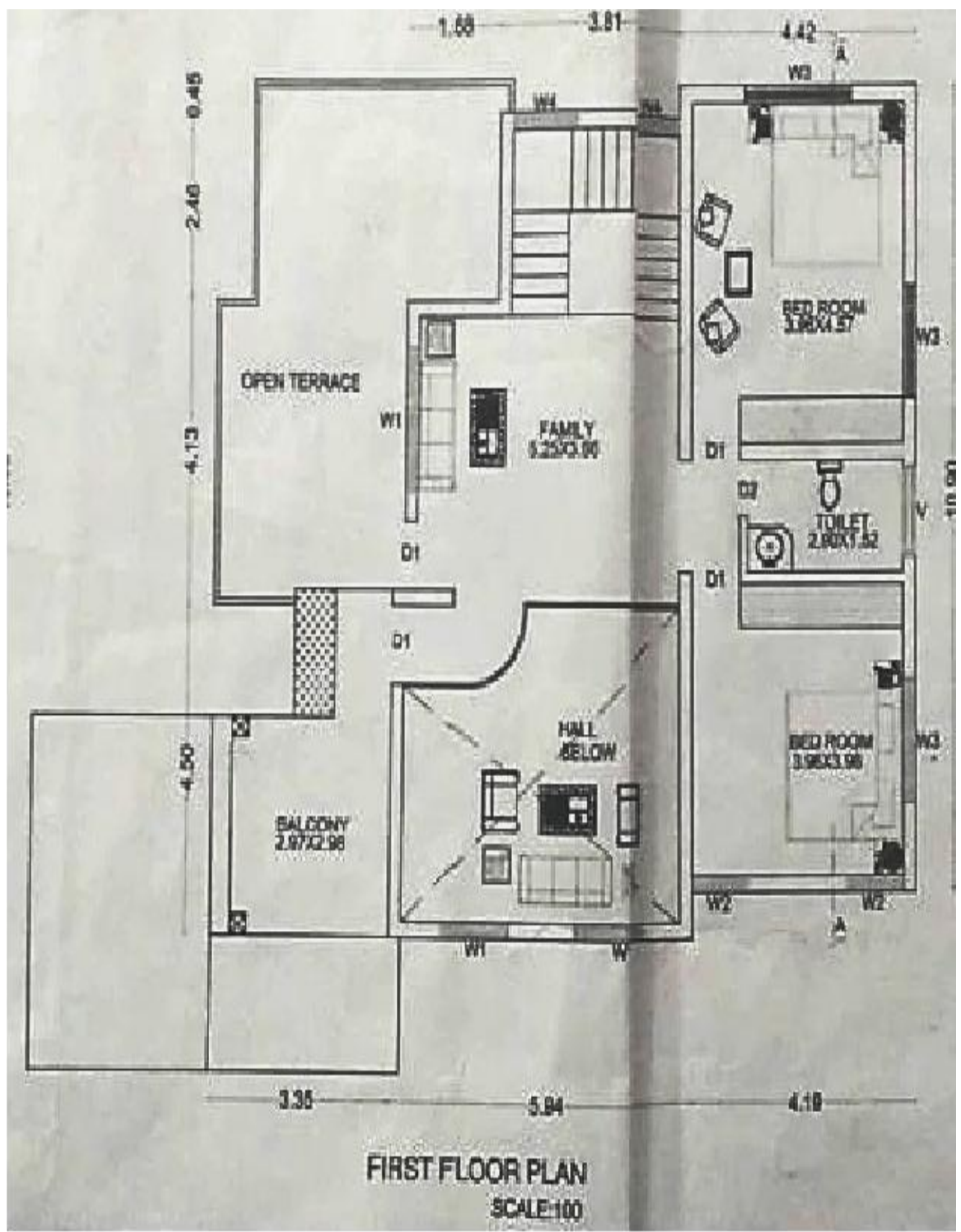

Fig.2. First Floor Plan 


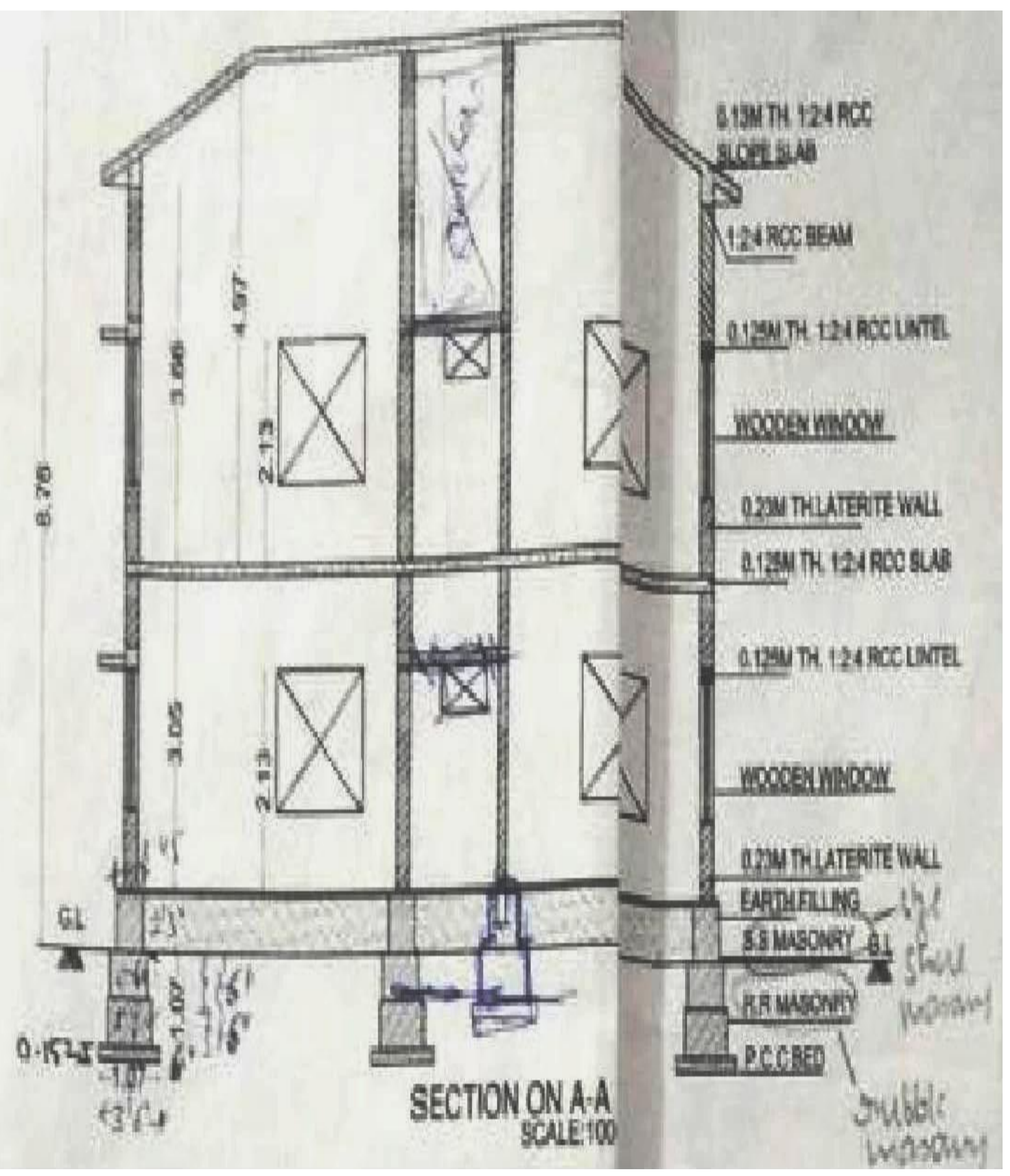

Fig.3. Sectional Elevation 


\section{REFERENCES}

1. Abhishek Golchha, S.S Pimplikar, "Valuation of Multi storied Building for Bank Finance Purpose", International Journal of Engineering Trends and Technology, Vol. 3, Issue. 5, May 2016.

2. Granger C. W. J., and Newbold P. "Spurious Regressions in Econometrics", Journal of Econometrics, 2: 1974 pp' 111-120.

3. Michael C. Dalbor, Andrew H. Feinstein \& Zhenxing Mao (2006) A Review of Restaurant Valuation Literature: The pre-2005 Perspective, The Journal of Hospitality Financial Management, 200614:1,pp. 43-51.

4. Peter Byrne, , "Fuzzy analysis: A vague way of dealing with uncertainty in real estate analysis?", Journal of Property Valuation and Investment, Vol. 13 Issue: 3,1995, pp.22-41.

5. Tse Y.R., , "An application of the ARIMA model to real-estate prices in Hong Kong”, Journal of Property Finance, 8(2), 1997.pp.152-163

6. Box G., and Jenkins G.,, Time Series Analysis: Forecasting and Control, Holden-Day, San Francisco. 1970

7. D. Krishnarajan., "Revised depreciation method for valuation of different floors of a building” Indian valuer, Vol. XLV,Nov 2013.

8. David A. Dickey, and Wayne A Fuller, Journal of the American Statistical Association, Vol. 74, No. 366, pp. 427-431, Jun.e 1979

9. N.Ravindran, "Valuation of a property by three methods" Indian Valuer 1, A Journal Of Institution of Valuers, pp 694-698, June 2006

10. Vinay Kaul, B.Prakash Rao,Harish Hedge "International Valuation for Advancing Credit to a private Limited Company." The Journal of The Indian Institute of Architects. issue no. 8, Vol. No. 70, September 2005 pp39-40

\section{AUTHORS PROFILE}

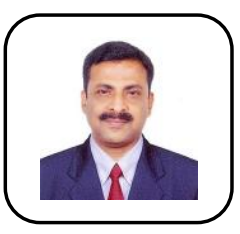

Prof. B. Prakash Rao Associate Professor(Senior Scale), Dept. of Civil Engineering, Manipal Institute of Technology, Manipal Academy of Higher Education, Manipal, India has published 21 papers in International Journals, 5 papers in National Journals, 11 papers in International Conferences and 21 papers in National(Indian) Conferences till date. He has visited 27 Countries till date of which 9 are for presenting papers in International Conferences 